\title{
MODUL KETERAMPILAN BICARA BAHASA ARAB MENGGUNAKAN MEDIA KOTAK SAKU
}

\author{
Achmad Robith Khusni ${ }^{1}$, Hasan Aziz ${ }^{2}$ \\ ${ }^{1}$ Universitas Islam Zainul Hasan Genggong \\ ${ }^{2}$ Universitas Islam Negeri Sunan Ampel Surabaya \\ ${ }^{1}$ khusnirobit@yahoo.com, ${ }^{2}$ hasan.alaziz45@gmail.com
}

\begin{abstract}
:
The Researchers see that the Arabic learning system at MTS Sirojut Tholibin is soo monotonous, only conveys what is in books and teaching materials and does not have a model or strategy in learning. While the purpose of this media is as additional basis and motivation so that students are more enthusiastic and creative in learning Arabic, especially Arabic in speaking skills. So the easy solution is that researchers will create modules or teaching materials based on Bithoqoh Jaybiyah, which is a pocket box for Arabic vocabulary. The Qualitative descriptive analysis approach with preliminary research using a defined and designed development model. This analysis will produce an Arabic vocabulary pocket box product for each student.
\end{abstract}

Keyword: teaching materials, speaking skills, pocket box.

\section{PENDAHULUAN}

Bahasa adalah pedoman dan alat dalam semua ilmu pengetahuan. Dimanapun berada jika tidak diperolehkannya kunci, maka pintu tidak akan bisa terbuka, begitu juga dengan Bahasa jika tidak mengenal Bahasa atau tidak belajar Bahasa maka pintu dunia tidak akan terwujud. Maka dari itu Kunci pintu dunia adalah Bahasa. Dengan Bahasa seseorang akan mampu menguasai dunia bahkan dari segala aspek baik ekonomi, social,pendidikan, dan budaya. Bahkan sejarah, ribuan peradaban, seluruhnya bi tercapai jikalau telah terbahasakan. Bahasa juga dipriorotaskan sebagai pembuka jalan masa depan manusia yang cerah. Materi bahan ajar juga sebagai penunjang anak didik sebagai bahan atau acuan dalam belajar.

Rusydi Ahmad Thua'imah mengartikan buku ajar adalah :

$$
\begin{aligned}
& \text { إن الكتاب المدرسي يثدتمل مختلف الكتب والأدوات } \\
& \text { المصاحبة التى ليتلقى الطالب مزهما المعرفة والتى } \\
& \text { يوظفها المعلم في البرنامج التعليمي مدّل أشرطة } \\
& \text { الستجيل و المذكرات والدطبوعات التى توزع على }
\end{aligned}
$$

$$
\begin{aligned}
& \text { الطلاب وكراسة التدريبات وكراسة الإختبار } \\
& \text { الدو ضوع الية ومرشد المعلم . }
\end{aligned}
$$

"Alat - alat dan berbagai macam jenis buku yang mampu mendukung dan mengembangkan pengetahuan siswa dalam proses pembelajaran adalah buku ajar atau modul. Dalam system pembelajaran salah satunya adalah menggunakan buku, diklat, $\mathrm{CD}$, buku dari pemerintah, LKS, dan panduan pengajar. " Thu'aimah juga mengatakan seperangkat alat informasi dan pengalaman pembelajaran serta nilai - nilai yang harus dikembangkan dalam jati diri peserta didik agar mempunyai keterampilan terttentu yang sinergi dengan kurikulum ${ }^{1,}$.

Keterampilan berbicara dalam bahasa arab adalah keterampilan peserta didik mampu merangkai kata - kata dengan benar sesuai tata bahasa arab yang baik, yang telah dipelajari sesuai dengan struktur bahasa

\footnotetext{
1 Rusydi Ahmad Thu'aimah, Dalîl 'Amal 'Idâd alMawâd al-Ta'lîmiyah li Barâmij Ta'lîm al-Lughal al'Arabiyah Li Nâthiqîna Bi Lughât Ukhrâ (Ribath: Mansyûrât alMuzhamah al-Islamiyah li alTarbiyah wa al-'Ulûm wa alTsaqâfah, 1988), 63-64.
} 
dalam ilmu tata bahasa arab. Dalam menciptakan media dalam keterampilan berbicara bhs arab adalah merupakan suatu proses pembelajaran yang efesien. Sedangkan media adalah sebagai alat penunjang untuk peserta didik untuk lebih menguasai berbicara bhs arab. Akan tetapi peneliti akan medesain sebuah modul maharah kalam dengan media bithoqoh jaybiyah dalam materi pembelajaran bahasa arab.

Untuk membantu bahan ajar ini berjalan sesuai dengan porsinya dan tidak mengakibatkan monoton dalam pembelajaaran. Diharuskan adanya strategi atau media penunjang sebagai kunci keberhaasilan anak didik dalam mengembangkan keterampilan berbicara Bahasa Arab. Serta memiliki ruang lingkup yang teratur dan sistematika pembelajaran yang disesuaikan dengan keterampilan bhs arab baik ditinjau dari segi kosa kata, tata cara mengucapkan, dan intonasi gaya bicara yang benar. Tidak lupa untuk bisa diaplikasikan dalam kehidupan sehari - hari baik dalam kelas, lingkungan, rumah dan sebagainya.

Bahasa arab merupakan kunci atau alat dalam berinteraksi baik secara lisan atau tulis. Berinteraksi atau berkomunikasi merupakan kemampuan dalam memahami dan menyusun kalimat yang disesuaikan dengan adanya informasi, perasaan, atau akal pikiran, serta bisa dikembangkan dalam ilmu pengetahuan, budaya dan teknologi. Menurut mustafa alGhulayani mengatakan sesungguhnya bahasa adalah kata yang bisa digunakan oleh setiap orang untuk menyampaikan ungkapan atau maksud yang mereka kehendak ${ }^{2}$. Bahasa internasional adalah bahasa bahasa arab yang banyak dipakai diberbagai literatur. Bahasa Arab juga sering disebut mempunyai kepustakaan besar disemua bidang ilmu pengetahuan ${ }^{3}$.

Mahmud kamil al - naqah bahkan menyatakan susungguhnya kemahiran dalam berbicara bahasa arab dapat ditemukan dari sisi aspek faktor lisan atau bahasa yang telah

\footnotetext{
${ }^{2}$ Mustofa Al-ghulayani, Terjemahan Jami al-Durūs al'Arabiyyah jilid I (Semarang: As-Syifa, 1992), 13.

Azhar Arsyad, Bahasa Arab dan Pengajarannya.(Yogyakarta: Pustaka Pelajar, 2010), 11.
}

dipelajari, bahkan dalam mempelajari bahasa aisng pun tidak akan lepas dari dari faktor tersebut. Berbicara dalam pembelajaran bahasa asing merupakan priorotas utama pada kurikulum pembelajaran. Bahkan keterampilan berbicara menurut sebagian praktisi juga mengatakan tujuan utama dalam program pembelajaran bahasa asing adalah keterampilan berbicara bahasa $a \mathrm{ab}^{4}$.

Dilihat dari sisi metodologi bahasa Arab itu juga digunakan berbagai cabang pengembangan ilmu pengetahuan khususnya ilmu ilmu yang berhubungan dengan literatu literarur arab, baik itu literarut - literatur kitab - kitab ulama' modern/kekinian atau salaf/dahulu. Perkembangan ilmu pengetahuan dan teknologi juga tidak akan lepas dari ilmu bhs arab. Karena Bahasa arab adalah sebagai penampung dan penunjang segala aspek kebutuhan bagi penggiat dan pengguna, serta bisa menyerap dari berbagai macam ilmu.

Kurikulum pendidikan memiliki implementasi bahasa Arab, agar bahasa arab itu terjaga keeksistensiannya. Bagi para pemerhati bahasa arab harus mumpuni dalam cabang ilmu bahasa arab diantaranya : ilmu hiwar (berbicara), qawaid (tata bahasa arab yaitu nahwu sorof), mutala'ah (telaah ilmu bahasa arab), mufradat (kosakata), insya'(keterampilan menulis bahasa Arab), imla' (keterampilan menyalin huruf bahasa arab dengan benar), mahfudat (kata - kata mutiara bahasa arab), tarjamah (pemindahan suatu kalimat ke bahasa yang lain), balaghah ( semantik Arab).

Keterampilan berinteraksi atau berkomunikasi dalam pengertian yang lengkap adalah kemampuan berwacana, ketarmpilan memahami yang bias menghasilkan teks lisan atau tulis. Bila diklasifikasikan dari segi pemahaman linguistic, maka keterampilan bicara Bahasa Arab bisa dijadikan empat bagian keterampilan diantaranya : 1 . Istima' (mendengarkan) , 2. Al - kalam (berbicara),

\footnotetext{
4 Mahmud Kamil an-Naqah, Ta'lìm al-Lughah al'Arabiyyah li al-Nāt șiqina Bi lughat Ukhrā, Madākhilu Tșuruq al-Tadrīs (Makkah al-Mukarramah: Jami'ah um al-Qura, 1985), 151.
} 
3. al - qira'ah (membaca), 4. Al - kitabah (menulis).

Empat keterampilan ini bisa digunakan untuk berdialog atau membuat suatu wacana dalam kehidupan sosial bermasyarakat. Dan juga akan melahirkan lulusan - lusan yang mahir berdialog dan menguasai bahasa arab dari berbagai bidang ilmu.

Berbahasa pada dasarnya adalah alkalām atau berbicara agar mampu berkomunikasi lisan secara baik dan benar. Di dalam mahārat lughawiyah didahulukan keterampilan berbicara dari pada keterampilan menulis, hal ini disebabkan oleh beberapa factor, diantarnya adalah (abdurrahman bin ibrahim $1429 \mathrm{H}: 33$ ) :

1. Dalam sejarah keberadaan manusia sejak dulu kala, diketahui bahwa mereka mampu berbicara sebelum mengetahui metode penulisan.

2. Anak balita sejak lahir belajar berbicara sebelum belajar menulis, Adapaun keterampilan menulis didapatkan pada jenjang pendidikan kanak-kanak.

3. Rata-rata manusia ketika berbicara mereka menggunakan bahasa ibu secara mutlak, kebanyakan diantara mereka tidak mengetahui tulisan dari bahasa yang mereka ungkapkan.

4. Ada beberapa bahasa yang diungkapkan akan tetapi tidak tertulis

Dalam kontek pembelajaran bahasa Arab, Shalah Abdul Majid alArabiy (1981: 138-139) menjelaskan bahwa keterampilan bicara Bahasa Arab terletak pada dua kemahiran: Pertama, kemahiran ucapan (maharatun anNutqi) yaitu kemahiran dalam melafalkan huruf-huruf sesuai dengan makhrajnya, dapat membedakan bunyi ketika berharakat dan mati, dan intonasinya secara individual. Kedua, kemahiran berbicara (maharah al-hadist) yaitu kemampuan mengkomunikasikan ide-ide pemikiran yang dapat dipahami oleh lawan bicara. Kemahiran yang terakhir inilah yang dapat menyampaikan ide-ide pemikiran kepada orang lain (lawan bicara). Untuk mencampai hal itu beberapa usaha telah dilakukan diantaranya dengan melakukan sebuah media yaitu maharoh kalam bersasis media kotak saku.

MTs Sirojut Tholibin akan berupaya melaksanakan evaluasi dan pengembangan dari berbagai ragam. Terutama pada model atau strategi dalam pembelajaran, upaya dalam pembenhan strategi ini peneliti akan membuat semacam produk berupa modul keterampilan bicara bahasa arab menggunakan media kotak saku. Strategi ini adalah slah satu keterampilan dalam mengupayakan dan menambah wawasan dari sisi berkomunikasi bahasa arab yang mempunyai mutu dan kreatifitas siswa dalam pembelajaran. Mufrodat pada media ini mengingat bisa dijadikan unsur bahasa untuk mempelejari bahasa asing khususnya dalam pembelajaran bahasa arab ini. Kepentingan komukasi sangat dibuthkan oleh siswa, jika tidak maka efektifitas dalam pembelajaran bahasa arab semakin sempit.

Media kotak saku bahasa arab di MTS sirojut tholibin adalah salah satu bentuk media pembelajaran dalam mengembangkan mutu dalam komunikasi bahasa arab. Siswa mampu mengaplikasikan dari media itu dengan cara menghafalkan kosa kata yang akan dibagikan setiap kelompok. Dilain sisi siswa mampu menghafal kosa kata bahasa arab dan juga mampu mempraktekkan di lingkungan sekolah, dan kehidupan sehari - hari baik dalam sekolah atau tempat tempat tertentu seperti pasar, kantin, masjid, ruang tamu dll. Karena metode ini akan dibagikan sesuai kelompok masing - masing.

Berdasarkan konteks penelitian di atas peniliti berhak akan mengkaji dan fokus untuk menunjang keberhasilan para pelajar dalam pengembangan maharotul kalam berbasis media bithaqah aljaibiyah di MTs sirojut tholibin probolinggo. Serta akan merefleksi bahan ajar yang peneliti aolikasikan dengan media bithoqoh jaybiyah.

\section{METODE PENELITIAN}

Penelitian akan dilakukan di MTS sirojut tholibin tiris probolinggo, dengan menggunakan pendekatan penelitian deskriptif kualitatif disertai dengan penelitian dan pengembangan yang mengacu pada 
model 4D yang diperkenalkan oleh Thiagarajan atau yang disebut dengan model 4P (pendefinisian, perancangan, pengembangan dan penyebaran). Pengembangan ini memiliki 4 tahapan yaitu define, designe, develop, dan disseminate.

Penelitian ini adalah tahap permulaan yang harus diperhatikan. Akan tetapi peneliti akan menggunakan dua model pada media bithoqoh jaybiyah atau kotak saku Bahasa arab diantaranya yaitu difine, designe. Pada saat uji coba ini data yang akan dicari adalah berupa respon, komentar, dari sasaran pengguna model. 2 model ini yang nantinya bisa membantu siswa guna menguasai keterampilan berbicara bhs arab dengan baik dan benar berikut dijelaskan.

\section{Tahap pendefisian atau analisis}

Tahap ini dilakukulan dengan cara menganalisis dan merancang dengan mengikuti syarat - syarat pembelajaran yang meliputi tujuan pembelajaran, konsep pembelajaran, dan pembetasan materi pembelajaran yang disesuaiakn dengan media bithoqoh jaybiyah.

Adapun langkah- langkahnya sebagai berikut: a. Analisis awal akhir

Kegiatan menganalisa kurikulum ini menetapkan masalah yang disandarkan pada modul dan strategi pembelajaran bahasa arab media kotak saku dengan mengevaluasi kurikulum yang berlaku. MTS sirojut tholibin masih mengandalkan kurikulum K13. Karena sejak tahun 2010 sudah mengembangkan kurikulum K13. Implementasi kurikulum K13 ini masih menggunakan pendekatan saintifik yang mengacu 5 tahap atau proses yang diklasifikasikan yaitu : tahap menanya, mengumpulkan informasi, mengamati, mengasosiasi atau menalar, dan mengomunikasikan. Sehingga dengan kurikulum uni mampu meningkatkan siswa yang disesuaikan dengaan media kota saku bahasa arab.

\section{b. Analisis peserta didik}

Peneliti berupayakan menganalisis peserta didik yang ditinjau dari karakteristik atau sifat yang ada pada kelas VIII MTs sirojut tholibin. Tujuan dari analisis ini adalah menyelidiki dan mengamati karakter dan latar belakang peserta didik yang meliputi kehidupan dan kebutuhan peserta didik. baik dari sisi sosial, pendidikan, atau lingkungan sekitar. Hasil analisis ini dapat digunakan sebagai bahan tahap awal dalam mengembangkan dan mengaplikasikan modul atau bahan ajar keterampilan berbicara bahasa arab berbasis media kotak saku.

\section{c. Analisis rancangan}

Analisis rancangan ini bertujuan untuk menyusun, menelaah, megevaluasi, secara terperinci dengan memperhatikan rancangan utama yang akan dubutuhkan dalam proses pembelajaran terhadap siswa. Rancangan ini akan didesain secara gampang dan mudah untuk dimengerti yang sesuai dengan kebutuhan siswa dalam belajar baik dan benar, dalam mengembangkan materi. Pembahasan materi ini yang akan diteliti merupakan materi yang sudah ada di buku paket yaitu pelajaran ketiga " adawatul madrosiyyah " atau mengenai kosa kata benda - benda yang berada di sekolah, kemudian siswa juga harus menyediakan bahan - bahan yang dibuthkan dalam membuat media kotak saku bahasa arab.

\section{Analisis kegiatan}

Analisis kegiatan atau tugas ini akan dilaksanakan dengan cara mengetahui rancangan terlebih dahulu kemudian dijelaskan metode media kotak saku bahasa arab yang disesuaikan materi bahan ajar . Dari hasil ini dapat mempermudah pendidik untuk mewujudkan harapan dan tujuan yang akan dicapai dengan menyesuaikan indikator keberhasilan hasil belajar.

\section{Tahap designe atau rancangan}

Tahap rancangan ini, peneliti akan menghasilkan sebuah produk media non elektronik yaitu bithoqoh jaybiyah atau istilahnya yaitu kartu saku/kotak kantong yang berisi kosa kata bhs arab. Kotak yang sudah dibuat ditempeli dengan kertas plano dan dihias sebagus mungkin. Kemudian akan disajikan kepada anak didik dengan menyesuaikan materi pembelajaran bhs arab pada siswa.

Terdapat beberapa kriteria yang harus dilaksanakan pada tahap perancangan ini diantaranya: 
a. Penyusunan ujian

Penyusunan ujian ini berguna untuk mengetahui tingkat pengetahuan siswa dalam menguasai bhs arab. Terutama keterampilan berbicara, oleh karena itu tes sangat membantu dalam menerapkan medai ini agar dalam proses belajar berjalan dengan produktif sesuai yang dibutuhkan pendidik.

b. Pemilihan sarana atau alat

Sarana atau alat yang akan diujicobakan yaitu memilih alat atau sarana yang tepat untuk menyajikan materi pembelajaran yang disesuaikan dengan tjuan pembelajaran. Dalam pemilihan alat atau sarana ini peneliti telag malukan kajian dan analsis yang sudah dirumuskan dan dijabarkan sebelumnya pada tahap define.. Bentuk dari Bahan Ajar maharotul kalam berbasis media bithoqoh jaybiyah ini adalah kotak yang menyerupai saku yang didalamnya berisi kosa kata bahasa arab.

c. Mekanisme media kotak saku bahasa arab

Mekanisme media ini berdasarkan hasil analisis peniliti dalam merancang dan menyusun sesuai modul yang akan diterapkan. Berdasarkan hasilnya peneliti akan menyajikan tata cara atau komponen menggunakan media bithoqoh jaybiyah kepada murid. Murid diharuskan mengetahui dan mempraktekkan dengan bahan bahan yang sudah disediakan.

d. Menentukan spesifikasi produk modul sebagai sumber bahan ajar

Pada tahap ini peneliti akan merancang modul sebagai bahan ajar siswa MTS sirojut tholibin. Yang disesuaikan dengan KI (kompetensi initi), KD (kompetensi dasar), indikator, materi, dan metode yang akan diajarkan. Soesifikasi ini akan disajikan kepada siswa sesuai kebutuhan yang diawali dari pembuatan media, cara pemakaiannya, dan praktek langsung dengan muhadasah sesuai materi yang sudah dipersiapkan.

e. Merancang modul yang akan diterapkan

Peneliti akan merancang modul untuk mempermudah bagi siswa ketika menggunakan media ini. Modul ini sebagai bahan rancangan yang akan diterapkan, rancangan modul ini berisi tata cara pengunaan media, praktek perkelompok, dan penerapan media pada tema "adawatul madrosiyah" yang ada di dalam buku paket. Kemudian kata benda dalama penggunaan media bithoqoh jaybiyah.

f. Lokasi penelitian

Lokasi penelitian ini berada di lembaga MTS sirojut tholibin racek - tiris probolinggo. Subyek penelitian ini adalah siswa siswi kelas VII di mts sirojut tholibin. Peniliti akan melakukan observasi pengumpulan data,wawancara dan tes hasil belajar. pada sub bagian ini peneliti akan fokus pada bagian metode pembelajaran baik ditinjau dari segi proses pengajaran bhs arab, problem lapangan, deskripsi tentang kemampuan berbicara bhs arab baik secara kebutuhan atau latar belakang siswa.

g. Respon siswa dan guru

Respon sangat dibutuhkan oleh peneliti tujuannya adalah untuk mengetahui sejauh mana media ini diterapkan oleh siswa, dilihat dari sisi kelebihan atau kelemahannya. Serta juga sebagai bahan evaluasi apakah layak diterapkan pada keterampilan berbicara bahasa arab.

\section{HASIL DAN PEMBAHASAN}

\section{Tahap define}

Faktor faktor yang harus jabarkan adalah merupakan siswa kelas VII yang disesuaiakan dengan kebutuhan dan kurikulum serta disesuai dengan mahaaroh atau keterampilan berbicara . Serta media bithoqoh jaybiyah yang akan diterapkan sebagai bahan ajar untuk anak didik.

faktor yang harus dilaksakan pada bagian perkembangan define ini adalah sebagai berikut :

\section{A. Analisis awal akhir}

Rata-rata usia didik kelas VIII mts adalah antara 12 - 13 tahun. Pada umumnya umur segitu rata - rata anak masih dalam pubertas. Ketika dalam belajar masih membutuhkan dukungan yang kuat bak dari orang tua, guru, ataupun masyarakat. siswa mts sirojut tholibin rata - rata datang dari berbagai daerah dataran tinggi yaitu pegunungan. Ini juga menjadi kendala dalam proses pembelajaran bhs arab. Peerta didik juga dari berbagai latar belakang pendidikan. 
Ada yang sekoalh di SD dan ada juga yang dari MI, pengunaan mata pelajaran bhs arab di lingkugan sekolah tersebut sangat minim. Guna untuk menjadikan mereka mempunyai jiwa semangat yang tinggi dibutuhkannya sebuah media yang bisa menghambat kemalasan.

Masalah dasar pada tahap ini adalah bahan ajar yang masih membutuhkan perhatian yang sangat khusus, dikarenakan sangat minimnya guru dalam proses belajar mengajar yang sesuai dengan kurikulum yang berlaku. MTS sirojut tholibin racek merupakan MTS masih berakreditasi C dan masih menggunakan K13. Implementasi kurikulum 2013 yaitu dilaksakanan dengan menggunakan pendekatan pembelajaran saintific 5 tahapan atau proses yakni : tahap mengumpulkan data, mengamati, menanya, mengumpulkan atau menyatukan beberapa informasi, mengkomunikasikan, menalar atau mengasosiasi. Sehingga modul yang akan dibutuhkan sukses untuk menunjang pengajaran dengan kurikulum yang berlaku yaitu kurikulum K13. Dalam komunikasi itulah peniliti akan menyajikan media kotak saku berusaha untuk memperbaiki metode pembelajaran bhs arab.

\section{B. Analisis anak didik}

Dalam proses ini peneliti menganalisis siswa yang ditinjau dari latar belakang siswa kelas VIII MTS sirojut tholibin racek. Peneliti melihat secara langsung di lapangan yaitu kelas yang sangat memprihatinkan dari dua puluh delapan siswa/siswi masih tidak menggunakan meja atau kursi alias beralaskan lantai. Jadi dalam proses belajar pendidik harus kelilinng ke setiap siswa/ siswa guna untuk mengetahui cara belajar anak didik baik menulis Bahasa arab atau membaca tulisan Bahasa araab. Dari sinilah penulis menganalisis yang masih membutuhkan fasilitas yang memadai agar anak didik mampu belajar dengan baik.

Media ini bukan penghambat melainkan sebagai pemacu semangat walaupun hanya beralaskan lantai. tapi antusiais para siswa sangat semangat. dan ketika peneliti menyuruh untuk mempersiapkan bahan bahan media pembuatan kotak saku. Setiap kelompok dalam jangka waktu satu minggu mereka bisa membawakannya dan mempraktekkannya. walaupuan yang bisa dinilai hanyalah 80 persen. Setidaknya peneliti bisa melihat ada sebuah hasil yang mana ada sekitar sepuluh anak didik mampu berbicara Bahasa arab sesuai materi yang diajarkan dengan menggunakan media kotak saku.

Kemudian juga masalah Bahasa yang digunakan anak didik di mts sirojuth tholibin masih minim sekali, bahkan masih banyak yang menggunakan Bahasa Madura. Dan agak kesulitan ketika penliti melihat para siswa yang masih menggunakan Bahasa Indonesia. Faktor ini menjadi penghambat proses pembelajaran. Akan tetapi dengan adanya media ini sedikit demi sedikit siswa mampu menangkap pelajaran dan bisa membiasakan berbicara Bahasa arab. Walaupun hanya sebatas di lingkungan sekolah atau kelas itu sudah sangat luar biasa, dikarenakan sangat jarangnya sekali Bahasa arab di daerah pegunungan kecuali di mts sirojut tholibin racek ini.

\section{Analisis konsep}

Dalam konsep ini tujuannya adalah untuk menyusun seerta merancang dengan teratur dan sistematis yang berdasarkan pada materi bahan ajar pada siswa yaitu berupa buku paket pada materi pokok "adawatul madrosiyah". Penggunaan konsep ini harus diperhatikan oleh siswa, tidak boleh bagi siswa bergeser sidikitpun dari rancangan ini. Karena dengan konsep ini siswa akan bisa mengembangkan proses bahan ajar. Hasil dari penelitian ini akan menghasilkan indikator yang berisikan sebagai berikut diantaranya adalah :

a. Menghafalkan kosa kata bahasa arab pada pokok pembhasan adawatul madrosiyah atau benda - benda yang ada di sekolah dengan sistem kelompok.

b.Setiap siswa harus memilki bithoqoh jaybiyah atau kotak saku yang berisikan kosa kata bhs arab yang sudah ditentukan oleh pendidik.

c. Sebelum masuk siswa dwajibakn menyetor kosa kata yang sudah dihafalkan sebelumya.

d. Setiap kelompok dawajibkan berbicara bhs arab dengan menggunakan kosa kataa yang sudah dihafal. 
e. Setiap kelompok harus menyediakan kertas plano, kardus bekas, gunting, dan lem untuk membuat kotak saku bahasa arab.

\section{A. Analisis tugas}

Analisis tugas ini berisi mengenai materi-materi yang akan diajarkan meliputi materi pokok maharotul kalam dengan menggunakan media kotak saku. Kegiatan ini berupa praktek muhadasah sesama kelompok masing - masing dengan menggunakan kosa kata yang sudah dihafalkan. Pendidik diaharpakan menguasai materi bahan yang tealh diajarkan. Dan mampu mengembangkan bahan ajar yang sudah dipelajari dan dikuasai dengan baik.

B. Analisis struktur isi

Struktur isi peneliti akan membeberkan materi bahan ajar, prosedural dan proses pengembengan media kota saku bahasa arab dari awal sampai akhir. Tujuannya adalah Agar siswa mudah untuk memahami dan memprakterkan dengan baik dan benar sesuai dengan konsep yang sudah ditetapkan di MTS sirojut tholibin racek.

C. Analisis prosedural

Peneliti akan mengevaluasi dan memperbaiki bagain - bagian penyelesaian tugas yang telah diujobakan dan dilaksanakan oleh siswa, baik secara materi dan konsep konsep dalam modul yang sudah dirancang sebelumnya. Harapan dari penelitian pada tahap ini adalah penleliti bisa mngetahui pada tahap manakah yang kuranng dalam proses pembelajaran media ini.

D. SpesifikasiTujuan Pembelajaran

Dari penyelesaian tugas dan konsep yang telah dilaksanakan. Maka peneliti akan menghasilkan tujuan proses pembelajaran tahap pemula atau dasar dalam penyusunan tes dan rancangan bahan ajar keterampilan berbicara berbasis media kotak saku. Tujuannya adalah Untuk meningkatkan keterampilan siswa dalam keterampilan berbicara bhs arab.Mampu mengaplikasikan dalam kehidupan sehari - hari yang disesuaiakan dengan materi pembelajaran bhs arab. Dan bisa menjadikan siswa termotivasi, karena adanya sebuah produk yang baru itu siswa akan lebih bersemangat dalam belajar dan tidak monoton. Media adalah sebuah perangkat alat untuk membantu dalam pembelajaran bhs apapun.

Khusus untuk keterampilan berbicara bhs arab siswa agar meraasa nyaman dan senang adanya media sebagai penunjang dalam meningkatkan kualitas pembelajaran bhs arab. Juga sebagai penunjang menghilangkan rasa malu media bertugas memperbaiki yang tidak layak dalam pembelajaran menjadi layak dan produktif. Dalam mencapai tujuan yang lebih baik dibutuhkan kesinambungan dalam model pembelajaran dan pengajaran yaitu dengan memperbaiki kembali dari segi kurikulum, materi, bahan ajar, dan metode pembelajaran.

\section{Tahap Perancangan/designe}

Peneliti pada tahap ini, akan membuat dan menghasilkan sebuah produk bahan ajar keterampilan berbicara bahasa arab dengan menggunakan media kotak saku. Hal hal yang harus dilaksanakan adalah sebagai berikut :

\section{A. Penyusunan tes}

Soal tes termuat dalam satu lembar yang berisikan muhadasah bhs arab. Dengan materi dari buku paket yaitu "adawatul madrasah". Kemudian siswa diminta untuk mempraktekkan muhadasah sesuai dengan kelompoknya masing - masing. Penilaian ditijau dari beberepa aspek yaitu kelancaran, intonasi bahasa, dan kosa kata bhs arab.

B. Pemilihan media

Berdasarkan pada analisis sebelumnya yaitu tahap define pemilihan media ini adalah berupa Bahan Ajar keterampilan berbicara berbasis media kotak saku ini adalah kotak yang menyerupai saku yang didalamnya berisi kosa kata bahasa arab dengan materi dari buku paket bhs arab yaitu "adawatul madrosah" yaitu benda - benda yang berada disekitar sekolah. Alasan pemilihan modul ini karena modul disusun secara sistematis dengan materi sesuai dengan kebutuhan siswa dan agar dapat digunakan belajar secara kelompok atau mandiri.

C. Mekanisme media kotak saku

Secara jelasnya, mekanisme kotak saku akan dijelaskan sebagai berikut :

1. Pembagian kelompok

Dalam pembagian kelompok ini dirancang oleh pendidik, yang mana akan 
membagi siswa beberapa kelompok. Idealnya dibagi menjadi 4 atau 5 kelompok disesuaikan dengan jumlah kelas, setiap kelompok berisikan 4 atau 5 anak didik. Pembagain kelompok secara merata ini atas dasar kemampuan setiap siswa. Dan disesuaikan dengan kualitas masing - masing kelompok dari kelas tinggi sampai kelas merendah.

2. mekanisme media bithoqoh jaybiyah

Pada bagian ini tata cara penjelasan mekanisme pembuatan media yang dibuthkaan dan tata cara menggunakannya : Penjelasan mekanisme :

a. Setiap kelompok ditugaskan membuat kotak yang serupa dengan buku saku/ kantong yang terbuat dari kertas pelangi atau karton.

b.Kantong yang sudah dibuat ditempeli kertas plano atau pelangi, dan dihiasi sedmekian rupa sekiranya bisa mneraik perhatian dan menambah semangat dalam menghafal kosa kata.

Memberikan nama kelompok masing masing pada kertas plano yang berisikan kantong, dengan jelas dan benar.

c.Untuk media penulisan setiap siswa ditugaskan meomotong kecil - kecil pada kertas plano, sekiranya potongan tersebut menyerupai ukuran buku saku.

D. Menentukan spesifikasi produk modul sebagai sumber bahan ajar

Menurut peneliti, setelah melakukan analisis bahan ajar, maka ditemukan beberapa kendala bagi murid untuk belajar. Diakarenakannya sangat minim buku paket, yaitu setiap dua siswa hanya mempunyai satu buku paket. Hal ini menjadi kendala bagi siswa dalam proses belajar. Di dalam buku paket pembahasan sub bab ke tiga yaitu "adawatul madrosiyah" ditemukan keterampialn berbicara akan tetapi hanaya minim sebataas percakapan tidak ada model yang lain, Maka solusi yang tepat adalah peneliti akan membuat modul atau bahan ajar keterampilan berbicara dengan media bithoqoh jaybiyah.

Bentuk atau spesifikasi modul ini berupa berupa modul cetak dengan ukuran A3 atau A4. Proses pengembangannya didalamnya berisikan KI (kompetensi inti), KD (kompetensi dasar), indikator, konsep, dan tujuan bahan ajar. produk yang akan dikembangkan adalah sistematika cara pembuatan media bithoqoh jaybiyah, penerapan meedia dalam bentuk muhadasah, contoh - contoh latihan muhadasah, kosa kata yang dibuthkan dalam muhadasah khususnya dalam materi bertemakan "adawatul madrosah", berupa benda - benda yang ada disekitar sekolah.

E. Rancangan modul yang akan
dikembangkan Bahan ajar keterampilan berbicara berbasis media kotak saku yang akan dikembangkan terdiri dari beberapa kegiatan belajar : Penjelasan cara menggunakan media:

a. Siswa diwajibkan menghafal mufradat minimal lima kosa kata dengan cara menulis sendiri bagi setiap pendidik.

b. Siswa mennghafalkan kosa kata bahasa arab untuk sebagai syarat masuk kelas yang mana dilakukan pada setiap jam pertama atau terakhir pelajaran.

c. Setelah bel berbunyi, siswa diwajibkan berdiri diluar kelas secara berderet setiap kelompok masing - masing.

d. Setiap anggota kelompok menyetor setiap hafalannya kepada ketua kelompok dengan cara bergilir.

e. Memilih ketua kelompok yang pandai dan cerdas, dan ketua kelompok mempunyai hak untuk menghukum bagi anak didik yang tidak menyetor hafalan.

f. Setiap Siswa yang absen masuk kelas, maka wajib menyetorkan hafalannya tiga kali lipat, agar mendapatkan efek jerah.

g. Setiap kelompok mengahafalkan muhadasah yang sesuai dengan tema "adwatul madrosiyah" yang telah disediakan oleh pendidik.

Penjelasan di atas jelas ini adalah merupakan media dasar bagi para pemula dalam menguasai keterampilan berbicara, disamping juga sebagai menambah kosa kata bhs arab. Dan juga bisa menjadi sebuah inovatif dan kreatif agar anak didik tidak terbebani dengan materi pembelajaran bhs arab.

Berikut dibawah ini foto hasil produk kotak saku Bahasa arab. 


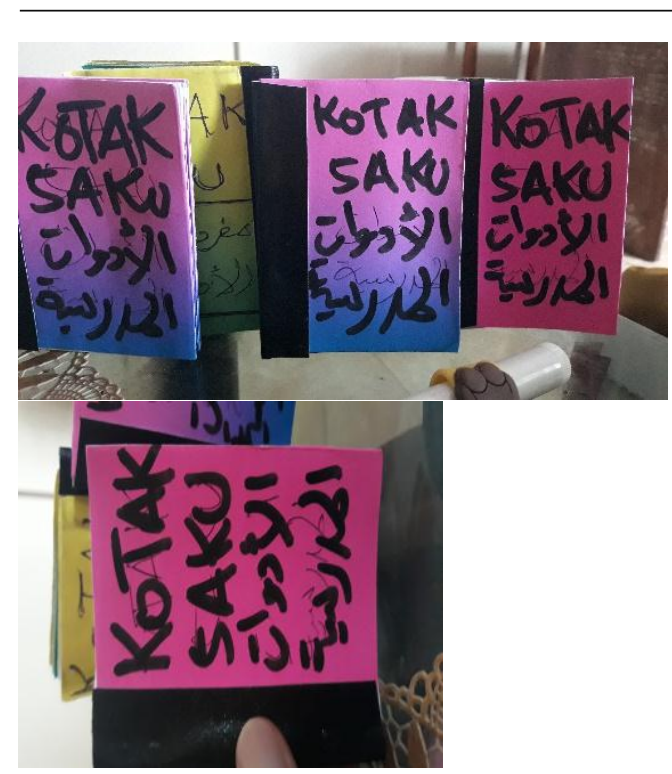

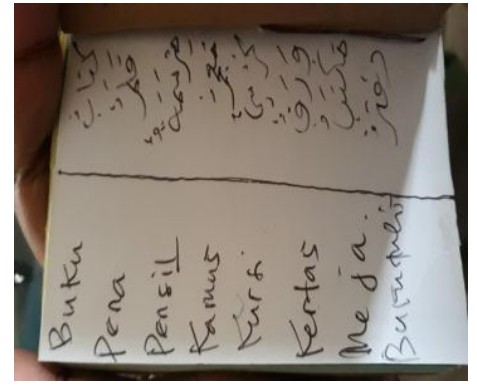

Inilah beberapa hasil produk kotak saku Bahasa arab, yang telah dikerjakan oleh siswa/siswi mts sirojut tholibin. Dengan pembuatan yang sangat simple yang teridiri dari kertas pelangi atau plano, gunting, lem kertas, kardus, dan spidol. Kemudian anak anak disuruh setiap kelompok untuk menulis beberapa kosa kata yang terkait dengan benda-benda yang ada di sekolah dan ditulis di dalam kotak saku kemudian di hafalkan.

Kemudian siswa/siswi disuruh satu persatu untuk menghafal kosa kata tersebut sesuai dengan kelompok masing - masing. Hasil ini sebagai nilai tambahan dan menambah wawasan yang berhubungan dengan keterampilan berbicara Bahasa arab. Kegiatan ini dilaksanakan sebelum masuk kelas.

\section{Respon siswa dan guru terhadap keterampialn berbicara Bahasa arab berbasis media kotak saku}

Stigma belajar bahasa arab adalah dianggap sebagai sebuah pembelajaran yang asing bagi mereka. Karena tidak adanya satu pun daearh atau sekolahan di sekitar mts sirojut thilibin racek yang mengajarkan bhs arab. Pembelajaran hanya sebatas tarjamah kitab pada literatur kitab - kitab kuning. Media bithoqoh jaybiyah ini menjadi sebuah bahan ajar yang sangat urgen dan cocok. karena materi ini sangat layak dan menambah siswa menjadi semngat untuk belajar yang Dan menjadi motivasi yang sangat kuat bagi anak didik.

A. Respon siswa

Media ini juga menjadi meningkatkan stigma belajar siswa. Respon anak kelas salah satu murid kelas tujuh yang bernama rangga mengatakan " bahwa belajar dngan metode sangat asik tidak menjadikan saya jenuh, tidak merasakan berat semua kosa kata hampir bisa saya hafal, dan media adalah pertama kali yang diajarkan“. Bakat siswa juga terlihat ketika mereka menghafal kosa kata kata benda baik benda - benda yang ada dikelas ataupun di halaman kelas. Mereka sangat antusias dengan adanya media ini.

Bahkan ada salah satu siswa yang tidak bisa sama sekali menjadi tau dan hafal katakata benda dengan baik dan benar, walaupun strategi dan metode ini masih butuh evaluasi. Titik tolak pada media ini juga sangat mempengaruhi pada siswa bagaimana tidak, tidak ada satu pun siswa yang mengeluh. Walaupun ada beberapa anak yang kurang begitu antusias dikarenakan tidak mempunyai bekal sama sekali bhs arab. Akan tetapi sedikit demi sedikit dia mau bisa megikuti fenomena ini dirasakan oleh siti aisyah salah satu murid kelas 7 mengatakan " baru kali ini saya menngenal media bithoqoh jaybiyah, jadi media ini menjadi penyemangat saya untuk terus belajar bhs arab karena saya tau bahwa bhs arab adalah bhs dunia yang harus dipelajari”.

B. Respon guru

Guru atau pendidik adalah sebagai penunjang keberhasilan siswa atau anak didik. Sejatinya guru mampu mengarahkan dan menghasilkan serta mencetak karakter siswa untuk pendidikan. Khususnya dalam bidang Bahasa arab guru harus sebagai pendamping dan menyesuaikan dengan mata pelajaran siswa.

Dalam media kotak saku ini pendidik ditugaskan sebagai pengawal dan menyeleksi 
proses belajar siswa serta menilai bagaimanakah kemampuan siswa dalam mempraktekkan media ini sebagai bahan ajar agar bisa mensukseskan siswa mampu berbicara Bahasa arab dengan benar. Maka peneliti untuk mengetahui sejauh mana media ini berjalan dengan baik sesuai konsep yang telah disediakan beberapa wawancara peneliti dengan guru Bahasa arab dan kepala sekolah mts sirojut thlibin racek.

Diantaranya peneliti mewawancarai kepala sekolah mts sirojut thilibin yang bernama pak yusuf, setelah melihat isi dan konsep media ini beliau mengatakan " media kotak saku ini adalah media yang sangat kreatif dan produktif bagi pembelajaran siswa tingkat pemula khususunya anak - anak mts. karena di sekolah khususnya di daerah pegunungan ini, banyak siswa yang datang dari daerah yang jauh dan jalan terjal serta banyak batuan yang sulit untuk dijangkau transportasi, seperti sepeda motor atau mobil. Akan tetapi hal ini tidak menjadi pebghambat belajar.

Bahkan siswa tetap semangat belajar Bahasa arab khususnya keterampilan berbicara Bahasa arab. Karena dengan adanya media ini satu satunya yang baru di aplikasikan di dalam sekolah ini. Jadi Peneliti mendapatkan apresiasi yang sangat banyak. Dan bisa menjadi pedoman dan pegangan dalam pembelajaran.

Kedua peneliti mencoba mewawancarai guru mata pelajaran Bahasa arab di mts sirojut tholibin racek yang bernama pak mulyono beliau adalah salah satu guru yang berpengarus di $\mathrm{mts}$ tersebut, dengan dengan rasa semangat menggebu beliau mengatakan “ media ini adalah salah satunya media yang jarang berkembang di sekolah - sekolah sini, karena banyak sekolahan yang belajar Bahasa arab khususnya di daerah tiris ini tidak menggunakan media, jangankan proyektor media keterampilan biasa aja tidak ada, hanya sebatas mengajar sesuai di dalam modul pelajaran Bahasa arab. Maka dari itu media ini sangat urgen dan cocok diajarkan untuk anak mts sirojut tholibin.

Maka dari sinilah peniliti melihat sangat dibutuhkannya media kotak saku Bahasa arab sebagai penunjang siswa pandai berbicara
Bahasa arab. Guru dan siswa sangat mendukung dalam proses pembelajaran modul ini. Sebagai bahan bahan ajar tambahan dan semangat siswa.

\section{PENUTUP}

\section{Simpulan}

Berdasarkan hasil peneliti pada tahap define dan designe maka modul keterampilan berbicara berbasis media bithoqoh jaybiyah dapat menghasilkan, diantaranya: (1) Peserta didik kelas VII mts sirojuth tholibin racek rata-rata masih dalam masa remaja antara umur 12 tahun, artinya siswa membutuhkan proses belajar dan dukungan yang sangat kuat baik dari pendidik dan orang tua; (2) kurikulum yang diterapkan pada modul ini berdasarkan kurikulum 2013 dengan tema “ aladawatul madrosiyah"; (3) bahan ajar yang akan disajikan hanya sebatas pada keterampilan berbicara bahasa arab; dan (4) Mengasilkan produk berupa modul untuk menambah strategi dan kemahiran berbicara bhs arab.

\section{Saran}

Saran peneliti adalah guru harus lebih kreatif dalam mengajar bahasa arab, dan memiliki strategi yang baru, serta selalu mengevaluasi kebutuhan siswa untuk semua maharoh tidak hanya maharotul kalam. Efektifitas guru harus benar - benar dijadikan acuan untuk siswa. Dalam pengejaran tidak boleh monoton, bagaimana sekiranya siswa itu senang dan bisa menikmati pelajaran dengan seamangat dan menyenangkan. 


\section{DAFTAR PUSTAKA}

Mustofa Al-ghulayani, Terj.Jami al-Durūs al'Arabiyyah jilid I. (Semarang: AsSyifa, 1992)

Azhar Arsyad, Bahasa Arab dan Pengajarannya. (Yogyakarta: Pustaka Pelajar, 2010)

Mahmud Kamil an-Naqah, Ta'lìm al-Lughah al-'Arabiyyah li al-Nāt șiqīna Bi lughat Ukhrā, Madākhilu Tșuruq al-Tadrīs. (Makkah al-Mukarramah: Jami'ah Um al-Qura, 1985)

Abdurrahman bin Ibrahim Al fauzan, Durūs al-Daurāt al-Tadrībiyah Li Mu'allimi allughah al- 'Arabiyyah Li Ghairi al-Nāt șiqina bihā. $(1429 \mathrm{H})$

Rusydi Ahmad Thu'aimah, Dalîl 'Amal 'Idâd al-Mawâd al-Ta'limiyah li Barâmij Ta'lîm al-Lughal al-'Arabiyah Li Nâthiqîna Bi Lughât Ukhrâ. Ribath: Mansyûrât alMuzhamah al-Islamiyah li alTarbiyah wa al-'Ulûm wa alTsaqâfah (1988)

Novira Nuraeni, "metode pembelajaran maharat kalam untuk meningkatkan keterampilan berbicara mahasiswa pada tingkat pemula". Nukhbatul ulum : jurnal bidang kajian islam Vol. 3 No. 1 desember 2017. (2017).

Ahmad Muhlis, "pengembangan pembelajaran maharah kalam berbasis bithoqoh jaybiyah". Okara : jurnal bahasa dan sastra Vol. 8 No. 122014. (2014)

Nurmasyitah Syamuan, "pembelajaran maharah kalam untuk meningkatkan keterampilan berbicara mahasiswa program studi pendidikan bahasa arab fakultas tarbiyah dan keguruan". Lisanuna : jurnal majalah Dauriyah ilmiyah fil llughotil arobiyah wa ta'limiha" Vol. 4 No. 2 2015. (2015)

Khoiru Nidak, "penyusunan bahan ajar untuk keterampilan berbicara bahasa arab". Lingua scientia : jurnal Bahasa lingua scientia" Vol. 10 No. 1 2012. (2012)
Risky Ramadhana S.siratte, "pengembangan modul pembelajaran berbasis keterampilan literasi”. Jurnal uin alauddin : inspiratif pendidikan" Vol. 6 No. 17 2017. (2017)

Hasan, james richard. habibie alvons. ismail, abdul qodir, "pengembangan bahan ajar berupa modul basics english grammer untuk mahasiswa tadris bahasa inggris FITK IAIN sultan amai gorontalo. Journal al - lisan : jurnal bahasa dan pengajarannya". Vol. 5 No. 12019.

Pransiska Toni, " buku teks al - lughoh al 'arobiyah al - mu'ashiroh bagi penutur non arab : desain kontruksi Dan implementasi. Al-fikra : jurnal ilmiah keislaman". Vol. 17 No. 12018. 